\title{
Gender and Tag-Questions in the Iraqi Dialect
}

\author{
Raed A. Albanon \\ Department of English, College of Education, University of Kufa, Najaf, Iraq
}

\section{Email address:}

Raeda.jawan@uokufa.edu.iq

\section{To cite this article:}

Raed A. Albanon. Gender and Tag-Questions in the Iraqi Dialect. English Language, Literature \& Culture. Vol. 2, No. 6, 2017, pp. $105-114$. doi: $10.11648 /$ j.ellc.20170206.13

Received: September 23, 2017; Accepted: November 8, 2017; Published: December 20, 2017

\begin{abstract}
The issue of inequality between males and females is a significant phenomenon in the Arabic world. Gender equality and women's freedom in the Islamic world generally, and the Arabic countries especially have always been questioned. These issues, no doubt, have an impact on the language of men and women. The teachings of the Holy Quran and the prophet Mohammad (PBUH), or let's say how people perceive them play a significant role in shaping the society, especially in a religious city like Holy Najaf where everything is centered on religion, and where the data of this study were collected. However, the understanding and application of these teachings are even more important in regard to putting in action the effects of these teachings on shaping men and women's language. This research was conducted to look at tag-questions and their different uses by males and females in that Iraqi city. The results were interesting in accordance with the social relationships between men and women and the power relationship coming from the Islamic constitution and the understanding of some men and women of this constitution.
\end{abstract}

Keywords: Gender and Language, Tag-Questions, Iraqi Arabic, Language and Power

\section{Introduction}

Much research has been done to explore the sociolinguistic stereotypes and codes of genders. Researchers looked into different types of social aspects of language use in gender interaction and gender bound nuances in various aspects such as pronunciation, vocabulary, usage, metaphor, syntax and communication. The most prominent work in this regard is [1] that caused controversies at the time. Lakoff argued that women have different ways of speaking than men in such a way that present them as subordinate towards men. Lakoff's whole impact is that women's language is depicted as "inferior and deficient" versus men's language being "superior" and representing the "norm" that women deviate from [2]. Since the time of Lakoff, language and gender has emerged as a distinguished interdiscipline.

The following paragraph is the gist of Lakoff's article [1],

I do feel that the majority of the claims I make will hold for the majority of speakers of English; that, in fact, much may, mutatis mutandis, be universal. But granting that this paper does in itself represent the speech of only a small subpart of the community, it is still of use in indicating directions for further research in this area: in providing a basis for comparison, a taking-off point for further studies, a means of discovering what is universal in the data and what is not, and why. That is to say, I present what follows less as the final word on the subject of sexism in language-anything but that!- than as a goad to further research.

Lakoff's claims have been influential [3]. It is already known that some of these claims on language and gender have been discussed, but most of these discussions were within the same language, i. e. English.

\subsection{Aim of the Study}

The purpose of this research is to examine Lakoff's claims about tag-questions in Arabic to see how applicable these claims are in Arabic. Lakoff [1] argued that an English tagquestion, is a midway in its usage and syntactic form between a direct open statement and a yes-no question, i. e., it is less confident than the former, and more confident than the latter. She also added that women use tag-questions more than men because women are more polite than men as tag-questions represent an invitation to the other interlocutors to converse.

\subsection{Significance of the Study}

I will look at the Iraqi Arabic and examine how tag- 
questions are used by each gender, in a religious Muslim city where everything is centered around a religion giving power to men, or at least that's how men perceive it [4].

O'Barr and Atkins [5] argued that the dominance features differ from one place to another depending on the social status. Therefore, different results are expected in this study. I believe that the results of this research will add to the literature of gender and language since the dominance is entirely different in Iraq. This difference is due to the structural and religious dissimilarity of the society especially in Holy Najaf where this research was conducted. Tag-questions are used a lot in the Iraqi dialect. This is one of the reasons why Arabic (especially Iraqi) speakers of English tend to use tag-questions more often being affected by their mother-tongue.

The forms and functions of the Iraqi Arabic tag-questions will be explained to shed light on how they differ from the English tag-questions. This will be a good insight into the analysis of the study.

\section{Background}

Gender and Language, dominance, difference, and deficit

In the last forty years, much research has been conducted to look into how men and women differ both in speech and writing. Perhaps, most researchers in this regard were influenced by or reacting to Lakoff [1], [6] who sketched the framework that led to the dominance theory. She drew the attention to how women's language differs from that of men's in such a way that depicts women as inferior to men. Before that, linguists focused on the morphological and phonological differences between women and men. Lakoff, however, added other areas to focus on, i. e., syntax (tagquestions), semantics (the use of colors), style, sociolinguistics (politeness) and so on. She mainly shifted the focus to the sociolinguistic field.

Probably unconsciously, Lakoff drew the attention to the idea of difference, usually associated with Tannen. She set up roots for the language of the specific gender and how "little girls" get scoffed at or scolded when they try to talk like "tough boys" and grow up having "soft language" and, hence get denied to access the power placements for "not being able to act tough." She also claimed that women, more often than men, use hedges, intensifiers, tag-questions and other forms indicative of uncertainty and/or hesitation.

Another notion Lakoff drew the attention to is the dominance theory which is traditionally attributed to Dale Spender, Pamela Fishman, Don Zimmerman and Candace West. It suggests that there are some features attributed to women's way of speaking and such features give the impression of subordination or inferiority, uncertainty, and eventually difference.

\section{Literature Review}

\subsection{Gender and Language}

Many researchers contradicted and critiqued Robin Lakoff and disputed her findings. O'Barr and Atkins [5] argued that Lakoff made a mistake when she considered "women's language" to be a gender marker instead of a status marker. In their research, they conducted a study in two societies of women with different statuses. They found that while women of lower status used some of the features described by Lakoff as "women language", women of higher status avoided these features most of the time. According to these findings, the whole idea of language difference between women and men then, is more related to the dominance or power theory than to the gender issue. Therefore, the dominance and difference theories are related, and this is the core idea of deficit.

Cameron [7] stated that the way women talk has commonly been compared by Tannen [8] to men's talk as opposites, e. g. men's talk is "competitive" while women's talk is "cooperative"; women "rapport talk" while men 'report talk' and analysts usually featured these opposites as markers of "competition" and "cooperation."

Trudgill [9], however, found out that women tend to use the phonetic variation $/ \mathrm{n} /$ instead of $/ \mathrm{n} /$ while men do not. This phonetic variable, i. e., / $\mathrm{g} /$ is considered prestigious in the Norwich English. So, in this case, Trudgill concurred with Lakoff regarding the fact that women tend to use a more prestigious style of language.

Another work in this regard was by Holmes [10], in which she looked into one of the differences in politeness between men and women. She stated that women and men use language in different ways simply because their perspective of language differs in regard to its function or to their definition to the purpose of language. According to her, that difference is why they interact differently. She argued that men use language mainly to elicit information while women use it for more social purposes and she continued that women are more polite than men. She claimed that women experience positive politeness (such as appreciation) while men use negative politeness (such as more respect) ${ }^{1}$. She referred, however, to some exceptions. She continues to say that women are more positive listeners than men, having a "better" way of disagreeing with the others without confronting, and use more compliments and apologies. In this regard, she examined Lakoff's claims and agreed with them.

Chang [11] conducted research on gender and language, but this time in a particular profession involving professors in the society of EPA or English for Academic Purposes. He examined questions, their frequency and functions among male and female professors. In agreement with Holmes [12] \& [3], Chang concluded that the frequency at which questions occur depends on the type of question itself.

\subsection{Tag-Questions}

The literature on English tag-questions is rich, most of which focused on the phonological and syntactic point of view; see for example [13] and [14]. On the other hand, Arabic tag-questions in general, have never been the focus of

1 Negative politeness and positive politeness were first identified by Penelope Brown and Stephen Levinson (1987). 
researchers both semanticians and sociolinguists. They have been discussed only briefly from the syntactic point of view. Only brief discussion could be found in a whole big book, as in [15] and [16], or we do not find them at all. At the time we see the focus of researchers shifted to the sociolinguistic aspects of tags in English, the social roles of Arabic tagquestions have been completely overlooked.

In general, researchers have studied tag-questions in two different ways. Some researchers looked at tag-questions in casual conversations, while others approached them in particular environments (the Asymmetrical approach).

\subsubsection{Asymmetrical Approach}

In this type of approach, researchers look at tag-questions in specific environments such as school, hospitals or military institutions.

Dubois and Crouch [17] examined the use of tag-questions in data collected from professional meetings. They found that men use tag-questions more often than women. Their aim was to examine Lakoff's findings and they argued that her claims were questionable because she based them on her own intuitions and observations.

Wehner [18] claimed that he added a new type of tagquestion to those of Holmes and called it "confrontational" tags, by analyzing one episode of "Hard Talk" TV show in which he looked at the speech of Tim Sebastian, the interviewer, who used tags 17 times in 25 minutes. He related that type of tag-questions to power where the interviewer is given the authority to control the conversation and the immunity to ask questions as he liked. In fact, it was a change of name rather than an addition. Holmes [19] already labeled that type of tag-questions and called it challenging tag-questions.

Harres [20] examined tag-questions used by three female Australian doctors, and occasionally by patients in the medical environment. She concluded that women tend to use tag-questions to maintain control of the consultations and to basically elicit more information from patients.

\subsubsection{Casual Approach}

In this type of approach, researchers conduct their research in the normal or casual conversations as in the case of the current study.

Lakoff [1] \& [6] investigated tags and argued that tagquestions are indications of unassertiveness. According to her, tag-questions are used in two different ways: "legitimate" and "illegitimate." The first type is used when the speaker needs confirmation from the addressee, while the second is used even when the speaker knows the answer but use it to elicit information or to make "small talk." She argued that the second type is used more often by women: "It is my impression, though I do not have precise statistical evidence, that this sort of tag-questions is much more apt to be used by women than by men."

Holmes [20], [12] \& [3] examined tag-questions and highlighted that they are not all of one kind, nor do they serve the same function. She established "Hence tags, for instance, are used more often by men than women to express uncertainty, while women use them more often than men in their facilitative positive politeness function." She divided tags into modal tags; used for certainty, and affective tags; used to invite the addressee to participate in the conversation.

In other research articles, Holmes [19] \& [22] divided tagquestions in more details into four functions: facilitative, softening, epistemic modal, and challenging.

- Facilitative tag-questions invite the interlocutor to participate in the conversation (e. g. nice weather, isn't it?)

- Softening tag-questions attenuate a criticism or directive (e. g. that was stupid, wasn't it?)

- Epistemic modal tag-questions are used when the speaker is uncertain (e. g. that was Jane, wasn't she?)

- Challenging tag-questions express aggression (e. g. I told you not to smoke, didn't I?)

Cameron et al [23] studied two cases and concluded that the relationship between the functions of tag-questions and their linguistic form is a more complicated paradigm even when using Holme's affective/modal classification. She also argued that the use of tags is related not only to gender, but also to the relative status of the interlocutors, objective of the interaction, and other factors. Cameron [23] did another study in that regard and decided that it is "not gender difference but the difference gender makes."

Nemati \& Bayer [25] compared women and men's language in regard to hedges, intensifiers and tag-questions in the Persian language. They did not see any significant differences between males and females. Their results rhymed with those of Holmes [10] \& [3].

\section{An Insight into Dominance and Difference in the Islamic Society}

The conversations of this research were recorded in the Holy City of Najaf, a religious city in Iraq, where women usually conduct according to the Islamic point of view. Dominance and difference, for their relevance to gender and language, will be reviewed in this city.

Before Islam was preached, women were not allowed to seek knowledge or study in any way. They were only allowed to write and memorize poems to entertain men. The prophetic saying came to change this entirely. Not only did the prophet allow seeking knowledge, but he made it a duty as well. He said, "Seeking knowledge is a duty for all male Muslim and female Muslim." In these times when a father is told that his wife gave birth to a girl, he remains sad all day and eventually kills the baby or buries her alive! Islam was preached to change that and the Quran blamed such actions:

"When one of them gets a baby girl, his face becomes darkened with overwhelming grief. Ashamed, he hides from the people, because of the bad news given to him. He even ponders: should he keep the baby grudgingly, or bury her in the dust. Miserable indeed is their judgment." (Quran 16:5859)

Although some verses in the Quran seem to "nominate" men as "leaders" of the house, or that how some people 
perceive it, the religious scholars, exegetes, and prophetic traditions did not interpret that as superiority to men; they insisted that these verses do not mean inequality between men and women. Unfortunately, not all Muslims understand these teachings. They adhere to the verse that apparently gives them the leadership of the house which is:

"Men are in charge of women..." (Quran 4:34)

And yet, they forget the following verse:

"I shall not lose sight of the labor of any of you who labors in My way, be it man or woman; each of you is equal to the other."(Quran, 3:195)

When it comes to discourse, the Quran often mentioned women besides men to reveal equality, especially when it comes to rights and duties:

"Verily for all men and women who have surrendered themselves unto God, and all believing men and believing women, and all truly devout men and truly devout women, and all men and women who are true to their word, and all men and women who are patient in adversity, and all men and women who humble themselves before God, and all men and women who give in charity, and all self-denying men and self-denying women, and all men and women who are mindful of their chastity, and all men and women who remember God unceasingly: for all of them has God readied forgiveness of sins and a mighty reward." (Quran 33:35)

The question remains: then, where does inequality between women and men in the Islamic societies come from? The problem lies in practice [4], [26]. There are some verses in the Quran that suggest superiority of men over women when these verses are taken out of context or interpreted by people rather than scholars. These verses were misunderstood and misapplied by many Muslims whether males or females [4]. The explainers (called Mufesireen), interpreters or exegetes of the Holy Quran, tried to reflect equality in these verses in the way that the prophet explained. One of these verses is:

"Men are in charge of women..." (Quran 4:34) (Sahih International, Pikhtal)

There are other translations/interpretations of this verse. It is translated entirely differently in such a way that removes any superiority to men over women:

"Men are the protectors of women..." (Sarwar, Yusuf Ali) ${ }^{\mathrm{i}}$

This difference in translation reveals the controversies and different understandings of the Holy Quran. No matter what this verse means; what really matters is how Muslim people perceive it. The society where this research is carried out is fourteen centuries away from the real meaning of this verse. Dominance is, no doubt, an issue that plays a major role in shaping the language of people. The dominance approach has been the opening subject of many researchers who discussed language and gender. It would be suitable to shed light upon this paradigm in the Arabic Islamic society where the "legality" that men are superior to women comes not only from the traditional heritage, but from the "religious beliefs" as well.

The difference issue in the Arabic and Islamic world is more complicated than it is in the western societies. Segregation between the sexes ranges between preferred to mandatory. The Islamic Shrei'a (law) and the Arabic traditions, forbid mingling of girls and boys even at early ages. It is also forbidden for a Muslim man and woman to be left alone in a locked room, called khalwa. Besides college, work is the only place where adults have the opportunity to talk freely. In some situations, women are not even allowed to go out or talk to a stranger without her husband's permission. This happens mostly in the religious societies. Both dominance and difference have a noticeable impact on the language of both men and women in the Iraqi society in general and the Najafi society in special.

\section{Data and Methodology}

Three casual conversations were recorded in Holy Najaf, a southern Iraqi city. The participants were three males and three females. They were not specifically told that this research is about tag-questions, but they knew it was about some linguistic study. The reason is obviously to make them avoid using tag-questions consciously and deliberately.

The three couples were chosen carefully as follows:

1- The first conversation was between a husband and his wife.

2- The second conversation was between a mother and her son.

3- The third conversation was between a female and male coworker.

The researcher analyzed each conversation and looked at where and when tag-questions were used. The formality and power relation are entirely variant in these three conversations. The relationship between the husband and his wife was previously explained that the husband usually has superiority over his wife according to their understanding of the Islamic instructions. In the second conversation, the mother has power over her son and sons in general have obedience to their mothers. This is, of course, one of the priorities of the Islamic instructions. In the third conversation, the male coworker has no power over his female coworker; instead, there are social rather than religious boundaries or limits they both have to keep. However, these boundaries are not related to power or dominance.

Besides gender, the diversity among the participants is expected to affect the usage of tag-questions and their types. The religious-social status is clearly noticed between the participants which makes a difference in tags usage following the power of speaker.

\section{Analysis}

\subsection{English Tag-Questions}

\subsubsection{Functions}

Holmes [21] divided functions of English tag-questions into two main types:

1- Modal tag-questions (fact-finding)

2- Affective tag-questions (interaction initiating) 
Modal tag-questions are the most common type which seek confirmation of what has been said. As in, (I heard that he bought another dog, didn't he/?)

Affective tag-questions are used to interact with the listener for the sake of participating in the conversation as in, (You like her, don't youl?). Another example of affective tagquestions is in the common conversation starter sentence, (Nice weather, isn't it?) where the speaker is not "uncertain" about how nice the weather is; rather she is just interested in the other's opinion.

A third type of tag-questions was described by Anderson [27]: "There are also other, less common uses of tags, such as the aggressive or hostile tags, which may, in fact, be humiliating rather than polite." This type is dependent heavily on the intonation as well as the length of the tagquestion. This type is similar to the one found in the interview by Wehner [18], where the interviewer has power of conducting the interview and controlling the course of conversation. It is also used frequently by police investigators or lawyers when talking to a suspect or crossexamining a witness. Examples:

Context: Investigator to a suspect.

You were present in the crime scene, weren't you/?

Context: Father to his son.

I told you not to smoke, didn't I/?

This type of tag-questions occurs also in dialogues between parents and their children, especially in a reproaching manner. Additionally, it can be seen in a teacherpupil dialogues.

Context: Mother to her son

I gave you $\$ 20$ just last night, didn't I?

\subsubsection{Forms}

Holmes [21] elaborated on dividing and subdividing tagquestions in English. As for syntax, she divided tag-questions broadly into two types:

1- The canonical tags

2- The invariant tags

The first type is relatively complex in which we can see the verb and subject as in, (the exam is on Monday, isn't it?)

The invariant tag-questions are simpler in syntax where there is no need for a subject or a verb. Just like the canonical tag-questions, they can occur in rising or falling intonations as in:

You are not going with us, eh/?

She doesn't like you, right $l$ ?

Holmes argued that the invariant tags such as right? and eh? might be considered hedges in some dialects and tagquestions in others depending on their functions.

\subsubsection{Polarity}

In regard to their polarity, Harres [20] divided tagquestions into two main types: constant polarity where both the statement and the tag-question are positive (which is rare in English), and reverse polarity where the statement is positive and the tag-question is negative or vice versa.

Reverse Polarity

She won't come, will she/?

\section{Constant polarity}

The boy is gone, is hel?

The framework for analyzing the data of the current study did not focus on polarity or form; rather, Holmes' approach of functions and Anderson's power tags were adopted. The other subdivisions of polarity and forms were explained briefly because they help in the analysis of the Arabic tags and create a form of comparison helps the English reader to see the full image.

\subsection{Arabic Tag-Questions}

\subsubsection{Functions}

As in English, Arabic tag-questions occur at the end of the sentence. They are called "al'as'ila al-thayliya" and literally means "tail-questions."

Aljaw jamil, alaysa kathalik/?

Nice weather, isn't it/?

By adopting the simple approach of Holmes [21] and that of Anderson [27], Arabic tag-questions can be labelled into three types:

1- Modal tag-questions (MTQ)

2- Affective tag-questions (ATQ)

3- Power tag-questions ${ }^{2}$ (PTQ)

As in English, Arabic tag-questions can be used to confirm information (modal tags) when the speaker is uncertain.

Akalta Almuza, alaysa kathalik/?

You ate the banana, didn't you?

The affective tag-questions are mainly used in Arabic to keep the conversation going and give a signal to addressees to take turn in the conversation.

Kam hua jameel an nasoom Ramadhan, ha/?

How nice that we fast Ramadhan, eh/?

The third type, power tag-question is usually used by those who have (or they think they have) power or superiority over the addressees. The usage of these tags, I believe, is not related to gender. It is related to the status let it be power or superiority. O'Barr and Atkins [5] critiqued Lakoff and argued that the latter made a mistake when she considered "women's language", including tag-questions, a gender marker instead of a status marker. We can see this type of tags occurring frequently in Arabic dialogues by males more than females in general, and by mothers more than other females within the female environment.

\subsubsection{Forms}

The two forms of Holmes [21] can be seen in Arabic as well. These are:

1 - The canonical tags

2-The invariant tags

The canonical tag-questions can only occur in Standard Arabic. There is only one canonical tag-question and it can only occur in Standard Arabic.

Alsama' tumtir, alysa kathalik/?

2 I chose this name as a general term to include both Holmes' challenging tags and Wehner's confrontational tags. I called it power tag-question simply because speakers who use them usually have power. In this study, this power comes from the religious teachings. 
(The sky) is raining, isn't it so/?

It is raining, isn't it/?

The only canonical tag-question is alysa kathalik. The literary translation is (isn't it so?). In English, this could mean all types of canonical tags, both the negative and positive forms. In Arabic, it has a fixed or concrete form that does not change according to the subject or verb of the statement.

\subsubsection{Polarity}

In Arabic, tag-questions are different in polarity. We can see the following types:

Akalta Almuza, Alaysa Kathalik?

You ate the banana, didn't you (isn't it so)?

Salim lam yathahab lil saff, sahih $^{3} /$ ?

Salim did not go to class, right/?

So far, we have seen the same two polarities of English: the constant polarity and reverse polarity. In Arabic there is a third type of polarity in which both the statement and tagquestion are negative:

Lam tuqith alsabi, alyasa kathalik/?

You didn't wake up the baby, didn't you (isn't it so)?

This type of polarity does not occur in English. I will call it negative constant polarity since both sides of the sentence are negative.

Another major difference between Arabic and English tagquestions is that in Arabic, there is no related subject or verb because all the Arabic tag-questions are concrete (do not change according to the subject).

Rafid wa Amir safraw, mu/?

Rafid and Amir travelled, didn't they/?

Firas safar, mu/?

Firas left, didn't he/?

In this review, I have explained basically what is needed to be aware of before looking into this study. Much of the above review related to Arabic tags was inspired merely from the examples themselves due to the lack of resources of the social treatment of Arabic tag-questions not to mention the Iraqi tag-questions. For the most part, Arabic tag-questions are slightly difference to the English tags.

\section{Detailed Analysis for Each Conversation}

\subsection{Conversation \#1}

Overall, the total tag-questions that were used both by the wife and her husband were ten. Eight of them were used by the husband, and two were used by his wife. Most husband's tag-questions were power tag-questions. He used five PTQs in the situation when his wife told him what he did not like. He used them mainly as a kind of reproach since he had the power to "control" her.

The following lines explain where the husband started to

3 Sahih is a standard Arabic word meaning right. It is used exactly as in the English way. get angry: ( $H$ for husband, $W$ for wife)

1-1 H: Mino hai almara?

Who was that woman?

1-2 W: Hai marat Salah

That's Salah's wife

1-3 H: Salah algassab, MUl?

Salah the butcher, right ?

[.......

1-4 W: Eeh... Rihtilhum lilbet da azorah.

Er... I went to their house to visit him

1-5 H: Ilman?

To whom?!

1-6 H: Kho mako shi?

You're kidding/?

1-7 H: Adri bes gutlich ma'reed tosleehum, MU/?

I know but I told you I don't want you to go to them, right/?

1-8 W: Adri at-thaker bes ziyarat almareedh wajba min Allah

I know, I remember but visiting the sick is a duty from God

1-9 H: Wajba bi ithn alzawj, SAHIH/?

A duty with the husband's permission, right/?

1-10 W: Almuhim khali ngheir almawdhou' raja'an Anyway, let's change the subject, please.

1-11 H: La, khalina bilmawdhou'

No, let's stick to the subject

1-12 H: Akeed gultila Abu Salam sallam 'aleik, HA:/?

I'm sure you told him Abu Salam sends you his regards, eh:/?

1-13 W: La ma gutla. Mashi gutlaah bes ma rah'ysadig

No I didn't. Ok I told him but he wouldn't believe it

1-14 H: Shlon 'erefti? Fitehti galbah?

How'd you know? Did you open his heart?

1-15 W: La bes adri bi y'orfak zain

No but I know he knows you well

1-16 H: Jamila, da alahidh inik thibeen tdhawjini halayam, $\mathrm{MU}^{4} \mathrm{SAHIH/?}$

Jamila, I noticed you like to piss me off these days, isn't (that) right?

1-17 W: Wallah mu qasdi adhawjak, bes gilit Allah Y'hib halshi, ZAIN ${ }^{5}$ ?

By God I didn't mean to piss you off, but I said God Likes this think, ok?

1-18 H: Be'den aani gutlich alqissa, MU:/? La'ad leish rihti?

Besides, I told you the story, right/? Then, why did you go?

$[\ldots . .$.

1-19 H: Tithakrin alsayarah al fiat illi rihna biha lilbasrah, ha?

You remember the red fiat (car) we went with to Basrah, eh?

$4 M u$ here is not a tag-question; it is a negation. Sahih is the tag-question in this sentence.

5 Zain is a very common word in the Iraqi Arabic especially. It means ok or well. It could be an adverb or adjective. 


\section{1-20 W: Hwaya henna}

They are plenty

1-21 H: Illi sawena biha hadeth. Inti chinti hamel biha, $M U / ?$

The one that we made an accident with. You were pregnant then, right/?

$$
[\ldots . .]
$$

In the first few lines, the husband used a modal tagquestions. It was merely a fact confirming tag. In fact, he used two modal tag-questions in the normal situation. He used one of them in the beginning (1-3) before he got the reason to be angry. He used the other one after his wife calmed him down in (1-21). As the conversation goes on, the wife tells her husband that she visited the family that he had already asked her not to have any contact with. This triggered the husband's anger. After that, he started cross-examining her using power tag-questions or PTQs that are relatively close to each other in the conversation. The intonation of PTQs was always rising as indicated by the slash (/) and sometimes stretched indicated by (:). He used five PTQs, see (1-7, 1-9, and 1-12) as examples.

The wife used two affective tag-questions basically to smooth the conversation and calm down her husband for example (1-17), while her husband used one ATQ only (119). She did not use any modal tag-questions or power tagquestions PTQ. This shows the woman's certainty in this conversation. The fact that the husband used more tagquestions indicates that the (religious) culture has a noticeable impact on shaping the language in this conversation. Most of these tags were PTQs which reflex the power of males in general and husbands in special. The wife unconsciously invited her husband to demonstrate his power tone by telling him the part of conversation that he did not like to hear. We find that there is an interaction between the religious fact that wives should never disobey their husbands and the linguistic concept of power tag-questions. The rising pitch of the tag-questions $m u$ and sahih in this conversation is typical of PTQs and tags in exclamatory situations.

In this conversation, the wife's submission to the fact that her husband has power over her is seen. This is the major difference of the situation in the religious environments than the situation in many other parts of the world. The "power" of men in the western world for example is not admitted completely by women. It is still debated and protested against as in the feminism movements and so on. This will, no doubt, affect the direction of the language in general and the tagquestions in special.

\subsection{Conversation \# 2}

\subsubsection{Mothers in Islam}

The Islamic teachings emphasized on revering the parents. It is important here to review the status and power of mothers over their children since this conversation is between a mother and her son. The Quran combines revering parents to worshiping God. In the Islamic society, mothers have dominance not only over sons and daughters, but this dominance might invite her to be superior over husbands in a few cases. Revering parents in general is stated in the following verse:

"Your Lord has decreed that you worship none but Him, And that you be kind to parents. Whether one or both of them attain old age in your life, say not to them a word of contempt, nor repel them, but address them in terms of honor. And out of kindness, lower to them the wing of humility, and say:' My Lord! Bestow on them Your Mercy as they cherished me in childhood" (Quran 17:23-24).

The prophet (PBUH) stressed the significance of mothers particularly more than fathers.

"A man asked the Prophet: 'Whom should I honor most?' The Prophet replied: 'Your mother'. 'And who comes next?' asked the man. The Prophet replied: 'Your mother'. 'And who comes next?' asked the man. The Prophet replied: 'Your mother!'. 'And who comes next?' asked the man. The Prophet replied: 'Your father.'”

\subsubsection{Conversation 2 Analysis}

In this conversation, the mother used four power tagquestions to question her son. She used them in a rising intonation and stretched pronunciation. ( $\mathrm{M}$ for mother, $\mathrm{S}$ for son).

2-1 M: Ham tdakhin Nargila, MU/:?

$[\ldots . . .$.

Again, you smoke hookah, isn't (that right)/?

2-2 M: Wilek ${ }^{6}$ treed tkhalif amri, MU/?

Hey! You wanna disobey me, isn't (that right)/?

2-3 S: La mama al'efo mu qasdi, bes ani ashofa habbab

No mom, I'm sorry I didn't mean to, but I think he is a good guy

$[\ldots . .$.

2-4 M: Abuk gal khali Majid yideer bala 'ala drasteh, ZAIN:/?

Your father said Majid should pay attention to his studies, $\mathrm{OK} /$ ?

$[\ldots . .$.

2-5 M: Gal ham khaleeh yiqallel t'al'ateh bil layl, ZAIN/?

He also said you should cut back on going out at night, ok/?

\section{2-6 S: Mashi mama}

Ok mom

This frequency of power tag-questions indicates that some tag-questions are not gender marked; instead, they are status marked. This supports what was emphasized by O'Barr and Atkins [5] who said that Lakoff should have considered "women's language" as a status marker instead of gender marker. The mother, with her God given status explained above, used PTQs with her son. This was completely different from the first conversation where the female never used PTQs.

The son used two ATQs for the same reason the wife did in the first conversation, that is, to calm down the mother by interacting with her and changing the subject.

\section{2-7 S: Bukra indik imtihan syaqa, sahihl?}

6 Wilek is an Iraqi slang word meaning hey (you)! It is used only when the speaker is of higher status. 
Tomorrow you have a driving test, right?

2-8 M: Iee bes hatha mu mawthu, na hassa.

$[\ldots . . . .$.

Yeah, but that's pointless now

2-9 S: Atmanna nrooh safra lil Habbanyah, ha?

I wish we can go in a picnic to Habbanya (lake), eh (what do you think)?

In many situations, affective tag-questions are used in the Iraqi Arabic to change the subject which also means changing the conversation tension into a lower level. As far as my knowledge reach, no one mentioned that as a function of the English ATQs.

\subsection{Conversation \# 3}

In the third conversation, the male co-worker used nine tag-questions, while the female co-worker used six. The relationship between the two co-workers in this conversation is of more formality than in the first two conversations. Besides family environments, colleges and coed schools, work is almost the only place where males and females have the freedom to talk for longer times, but still within the limits of Islam. For that reason, all the tag-questions used here are either modal tag-questions MTQs or affective tag-questions ATQs. No power tag-questions were used in this conversation for none of the co-workers have authority over the other. The situation might differ, however, if one of the workers were a boss of the other.

The male co-worker used most of the affective tagquestions at the beginning of the conversation.

3-1 M: Ya'ni, mathalan, aku nas ydawmon bil waqet $w$ aku nas la, MU SAHIH?

I mean, for instance, some people come to work earlier than others, isn't (that right)/?

3-2 F: Sedaqet wallah

You said the truth (You're right) by God (I swear)

3-3 M: Ya'ni, mathalan, almukhlis fi'lan ma yeh'taj [bassma], ZAIN?

I mean, for instance, the really devoted ones don't need a [fingerprint] (time clock)

3-4 F: [Sahih]

$[\ldots . .$.

[Right]

3-5 M: Sima'na halkalam bes maku shi malmos

We heard this speech (these rumors) but nothing concrete

3-6 Mnein sima'ti? Akeed Sit Hanan, HA? Hahaha /laughing/

Where from did you hear it? (I'm sure) Miss. Hanan, $\mathrm{eh} /$ ?

3-7 F: /laughing/ Aku gherha?

/laughing/ Who else?

All the affective tag-questions where used in a neutral or falling intonation. On the other hand, all the modal tagquestions where used in a rising intonation. So far, we can always rely on this rule to distinguish between these two types. However, it is not always obvious how to distinguish between MTQs and PTQs for both can have a rising intonation. Usually, PTQs are used with a rising intonation in a stretched pronunciation, especially the two tags: MU:/ and HA:/. SAHIH and MU SAHIH can rarely occur in a stretched pronunciation.

Most MTQs where used by the man in the part where the participants discuss a technical issue the male was not familiar with. He uses MTQs frequently, because he had no background about the new device (the time clock) fingerprint.

3-8 M: Hatha jihaz albassma diktor mh'mmad jaba, MU/?

This fingerprint (time clock) was brought by Dr. Muhammad, isn't (that right)/?

3-9 F: Na'am

Yes

$[\ldots \ldots]$

3-10 M: Yishtighil 'al hasiba, HA/?

It works with the computer, eh/?

$[\ldots .$.

3-11 M; Inti ikhtisass hasoob, MU/?

Your field is computers, isn't (that right)/?

3-12 F: La. Ani muhandisa madani

No, I'm a civil engineer

3-13 M: Yamta tkharajti? 2009, MU/?

When did you graduate? 2009, isn't (that right)/?

The woman used less MTQs even when she spoke as much as her co-worker. She used them relatively for the same reason, that is, to check for her information. She used three ATQs which is the same number that her male co-worker used. There is no difference in ATQs usage and number. Lakoff [6] argued that tag-questions are sometimes used for the sake of politeness. Holmes [10] stated that the affective tag-questions are used for this regard. This tells us that both the female and male co-workers have the same degree of politeness.

The following table and figure show the detailed and total use of tags in the three conversations:

Table 1. Total occurrence of tag-questions of all types in the three conversations.

\begin{tabular}{llll}
\hline TAGS USED & TOTAL TAG NO. & MEN & WOMEN \\
\hline PTQ power tags & 9 & 5 & 4 \\
ATQ affective tags & 11 & 6 & 5 \\
MTQ modal tags & 12 & 8 & 4 \\
ALL TAGS & 32 & 19 & 13 \\
\hline
\end{tabular}

For each conversation, the following figures show tagquestions, by males and females:

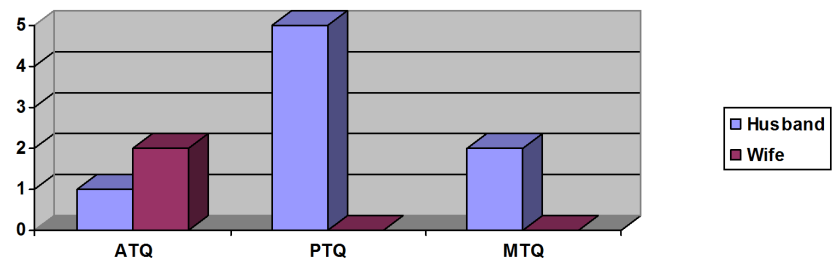

Figure 1. Tag-question occurrence in the first conversation. 


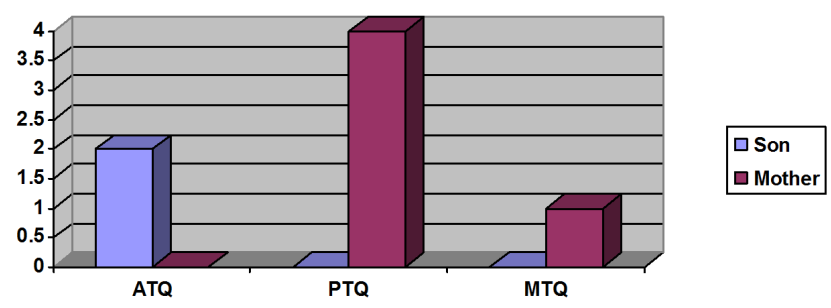

Figure 2. Tag-question occurrence in the second conversation.

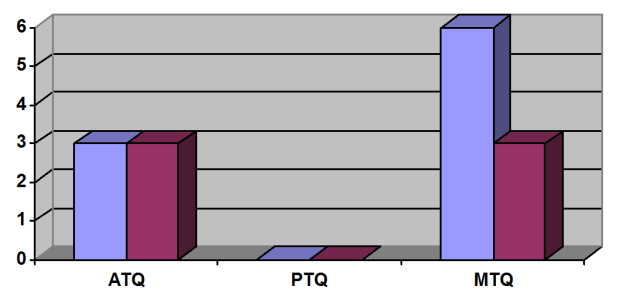

$\square$ Male Worker

$\square$ Female Worker

Figure 3. Tag-question occurrence in the third conversation.

\section{Conclusion}

The occurrence of tag-questions is quite frequent in the Iraqi Arabic. The significance of the social status (which is related to the religious society of Iraq), shows that the PTQ is used by both men and women. Power tag-questions are dependant on status rather than gender and this is in consistent with O'Barr and Atkins [5].

No noticeable difference in ATQs was found between males and females. They were mostly used to smooth the conversation and also to invite the others to participate in the conversation. The religious environment affects language in as far as gender is involved. The results rhyme with Nemati \& Bayer [25] who didn't find any significant differences in tags usage between men and women in Iran which has a similar society as Najaf.

The results are not in agreement with Lakoff's. In spite of the small number of conversations, the results have shown a variety of tags and their relation to the speakers' status. As it can be seen, the use of power tag-questions PTQs changes as we move from the first to the second conversation due to the status change of relationships between the male and female participants. It also affects the occurrence of modal tagquestions. There is a balance between modal tag-questions and power tag-questions; that is, the MTQ is less whenever PTQs are more. The reason is that the participants with a lower status are not expected to use interrogative sentences and tag-questions that are seeking information. The numbers of MTQs and PTQs are never the same or even close in number.

We have seen a rather new function of ATQs. There was a dual function for these types of tag-questions of changing the subject and reducing the tension of the conversation. We can see that clearly in the first and second conversations. The absence or existence of power for speakers affects the usage of tag-questions type as we can see in the last conversation.

This study is a pioneering step towards the sociolinguistic nature of Arabic tag-questions in general and Iraqi Arabic in special. No expanded study of Arabic tag-questions has been conducted as far as my readings go.

The power that men demonstrate in that city is of a religious nature. It is more significant and of more effect on language than the powers of other aspects like the one emerging from social aspects in different parts of the world. The social boundaries that the participants had to keep are of less effect than the religious dominance given to a husband or mother. This is the reason for the absence of PTQs in the third conversation.

Future researchers could find surprisingly different results in the rural areas and countryside of Iraq. Men in these parts of the country tend to demonstrate and show power not only with their wives or daughters, but also with stranger women as well. Results would also be different if this research was conducted in Baghdad, the capital of Iraq. The people there are more open to the western culture and religion there is less central than it is in Najaf.

\section{Acknowledgements}

I'd like to show my full appreciation to Dr. Sage Graham from the University of Memphis for her guidance throughout the research paper.

Special thanks to my colleagues at the University of Memphis Ms. Melissa N. Barrera, Dr. Utku F. Unsal and Dr. Rooh Ul Amin Khattak for their valuable support and suggestions throughout the paper.

\section{Appendix}

$$
\begin{aligned}
& \text { Appendix of Symbols Used in Transcription } \\
& \text { [ ] Square brackets indicate overlap } \\
& \text { ( ) The talk inside was not literarily said but } \\
& \text { WORD Capitalized word means the word in question } \\
& \text { I Rising intonation } \\
& 1 \quad \text { Falling intonation } \\
& \text { : } \quad \text { Stretched intonation } \\
& \text { [...... }] \text { This part of conversation was not transcribed } \\
& \text { a', e' or i' A glottal stop which is common in Arabic } \\
& \text { 'a, "e or ' } \mathrm{i} \text { Another glottal velar stop as in "'eyn" } \\
& \text { meaning "eye" } \\
& \text { h' } \\
& \text { Another velar glottal stop as in the word } \\
& \text { "h'ub" meaning "love" }
\end{aligned}
$$

The apostrophe in the Arabic transcription in general indicates that the sound is a little different than the English one.

\section{References}

[1] Lakoff, Robin. (1973). Language and Woman's Place. Language and Society 2 (1): 45-80.

[2] Talbott, Mary. (2010). Language and Gender. $2^{\text {nd }}$ Ed. Cambridge, MA: Polity Press.

[3] Holms, Janet. (1990). Hedges and Boosters I Women's and Men's Speech. Language and Communication 10 (3), 185205. 
[4] Badawi, J. A. (2002). Gender equity in Islam (Vol. 2, pp. 427428). IDM Publications.

[5] O'Barr, W and Atkins, B. (1980). Women's Langue or Powerhouse Language? In S. McConnell-Ginet et al. (eds.) Women and Language in Literature and Society. New York: Praeger.

[6] Lakoff, Robin. (1975). Language and Woman's Place. New York: Harper Colophon.

[7] Cameron, Deborah. (1997). Performing Gender Identity: Young Men's Talk and the Construction of Heterosexual Masculinity. In Sally Johnson and Ulrika Hanna Meinhof, Language and Masculinity (47-64). Malden, MA: Blackwell.

[8] Tannen, D. (1990). You just don't understand. New York: Ballantine.

[9] Trudgill, Peter. (2010). Sex, Covert Prestige. In Sally Johnson and Ulrika Hanna Meinhof, Language and Masculinity (2128). Malden, MA: Blackwell.

[10] Holmes, Janet. (1995). Women, Men and Politeness. London: Longman.

[11] Chang, Yu-Ying. (2012). The Use of Questions By Professionals in Lectures Given in English: A Cross-Gender Comparison. Taiwan International ESP Journal 3 (2), 19-50.

[12] Holmes, Janet. (1986). Functions of You Know in Women's and Men's Speech. Language in Society 15 (1), 1-21.

[13] Huddleston, R. (1970). Two Approaches to the Analysis of Tags. Journal of Linguistics 6, 215-221.

[14] Armagost, J. L. (1972). English Declarative Tags, Intonation Tags and Tag Questions. Studies in Linguistic and Language Learning 10, 1-53.

[15] Watson, Janet C. E. (2002). The Phonology and Morphology of Arabic. New York: Oxford.

[16] Smrž, Otakar. (2007). Functional Arabic Morphology: Formal System and Implementation (published dissertation). Charles University. Prague, Czech Republic.

i Translations of the Holy Quran are from:

http://corpus.quran.com/translation.jsp?chapter $=4 \&$ verse $=34$.
[17] Dubois, B. L., \& Crouch, I. (1975). The question of tag question in women's speech: They don't really use more of them, do they? Language in Society 4, 289-294.

[18] Wehner, L. W. (1999). Tag Questions in News Interviews (unpublished master's thesis). Aalborg University. Aalborg, Denmark.

[19] Holmes, Janet. (1983). Functions of Tag Questions. English Language Research Journal 3, 40-65.

[20] Harres, Annette. (1998). But Basically You're Feeling Well, Are You?: Tag Questions in Medical Consultations. Health Communication 10 (2), 111-123.

[21] Holmes, Janet. (1984). Hedging Your Bets and Sitting on the Fence: Some Evidence for Hedges and Support Structures. Te Reo 27, 47-62.

[22] Holmes, J. (1997). Women, language and identity. Journal of Sociolinguistics, 1 (2), 195-223.

[23] Cameron, D., McAlinden, F., \& O’Leary, K. (1988). Lakoff in context: the social and linguistic functions of tag questions. Women in their speech communities, 74-93.

[24] Cameron, D. (1992). Not gender difference but the difference gender makes' - explanation in research on sex and language. International Journal of the Sociology of Language, 94 (1), 13-26.

[25] Nemati, A., \& Bayer, J. M. (2007). Gender differences in the use of linguistic forms in the speech of men and women: A comparative study of Persian and English. Language in India, $7(9), 1-16$.

[26] Mashhour, A. (2005). Islamic law and gender equality: Could there be a common ground?: A study of divorce and polygamy in Sharia Law and contemporary legislation in Tunisia and Egypt. Human Rights Quarterly, 27 (2), 562-596.

[27] Andersen, G. (1998). Are tag- questions questions? Evidence from spoken data. Paper presented at the 19th ICAME Conference, Northern Ireland. 